Mendel, J.L. 1962. Trends in pulpwood production and consumption in the central states. Tech. Pap. 188. Cent. States FES. 10 pp.

and D.A. Gansner. 1962 Veneer-log production and consumption in the central states. Tech. Pap. 189 CSFES. 7 pp.

and D.W. Kaney. 1962. Cooperage logs and bolts production and consumption in the central states 1960. CSFES. 2 pp.

Ward, J. C. 1962. Stack drafts provides optimum ignition and coaling conditions for charcoal production. Tech. note 619 LSFES. 2 pp.

Wilson, B.F. 1962. A survey of the incidence of ring shake in eastern hemlock. Harvard For. Pap. 5. 11 pp.

\title{
ABSTRACT OF 1962 U.B.C. M.F. ThesIs
}

Variation in lodgepole pine and its role in the genetic improvement of coastal forms. By Lawrence Roche.

The thesis is divided into two parts, Part one deals with variation in a number of important silvicultural and taxonomic characteristics of Pinus contorta. Variation in bark and growth habit was studied in the field and recorded by means of photographs. The data obtained in this manner are supplemented by information concerning variation in both these characteristics in Lodgepole pine plantations in Europe.

It is concluded that the Shore form of Lodgepole pine is extremely intolerant of shade, and is not inherently a scrub tree, or inferior in form to the Inland variety of the species. The geographical position of some superior coastal stands is given.

The field study further showed that because of its shade intolerance the Shore form is restricted to the forests' edge, to ocean cliffs, sand dunes and muskeg. There its potential growth habit and form are obscured by extremes of environment, and observed only when grown in plantations, or in its natural habitat when competing species are eliminated by fire. Under the latter conditions the Shore variety of Lodgepole pine is a rapidly growing tree, with normal growth habit and form, and is seldom contorted either in bole or branch.

The Shore form has a characteristic bark type which is inherently different from the Interior form.

A study of variation in needle morphology was made on material obtained from trees of the Lodgepole pine provenance trial at The Institute of Forest Genetics, Placerville, California. Needle width and length were measured and it is demonstrated that a correlation between these two measurements exists. Because of this correlation the Shore and the Interior populations cannot be distinguished by either leaf width or length alone. Therefore the mean ratio of width to length is used to separate the variation in leaf morphology due to the place of origin of the trees from which the needles were collected. Analysis of variance shows that the mean ratio does not differ significantly between trees representing a particular site; between sites the difference is just significant, and between geographic regions highly significant. The Duncan 
multiple range test showed that the three major regions (Rocky Mountains, Sierra Nevada, Coastal) differed significantly from each other, but that there was no significant difference between the mean ratio of the Coastal and the Mendocino White Plains material.

Data concerning the growth rate of the trees at Placerville, supplemented by data from European plantations, suggest that coastal Washington and Oregon provenances show the most rapid growth rate in North Temperate regions.

Specimens of seed and foliage collected from natural populations show morphological differences between the Coast and Interior forms.

A method of distinguishing Coast and Interior seed is demonstrated.

Germination tests show that under standard conditions of temperature and humidity the rate of germination of the Coast seed is significantly different from that of seed from Interior sources. Morphological differences in seed characteristics can, therefore, be supplemented by germination data to effectively separate the Interior and Coast forms of Lodgepole pine.

Part two of the thesis deals with the selection and breeding of the Shore form. The proposed breeding program takes into account the theoretical and practical objections to the Scandinavian method of tree improvement. Nevertheless, it incorporates this method insofar as it is designed to produce large quantities of seed which is not inferior in several desirable characteristics, while simultaneously working for the genetic improvement of the species.

GILBERT C. CUNNINGHAM

Gil Cunningham died suddenly at Fredericton, N. B. on July 1.

Gil was born in Burlington, Vermont, in 1915 and the family moved to New Brunswick shortly afterward. He attended high school in Fredericton and, subsequently, the University of New Brunswick where he was graduated in 1943 with the degree of B.Sc. in Forestry. He immediately enlisted in the Canadian Army, serving as Lieutenant.

Gilbert was a senior forest research officer with the Federal Department of Forestry at Fredericton. Prior to this, he spent 13 years in Ottawa with the Forestry Branch. He was author and collaborator in two well-known Canadian publications. "Native Trees of Canada", and "Forest Flora", as well as many other technical articles and reports in his main fields of forest botany and silviculture.

Gil was also active in Institute affairs and served as Chairman of the Ottawa Valley Section in 1954-55.

His wife Margaret predeceased him several months ago. To his children James Cameron and Katherine Anne, is extended the sympathy of the members of the C.I.F., and his many friends and associates. He will be missed by the many foresters with whom he worked at Ottawa and Fredericton, and by many other professionals working in the fields of forestry and botany.

W. W. Calvert and E. L. Hughes 